\title{
Minutes of the Assembly of the Brazilian Crustacean Society
}

Sérgio Schwarz da Rocha, Cléverson Ranniéri Meira dos Santos and Fernando L. Mantelatto

(SSR) Presidente da Sociedade Brasileira de Carcinologia, Universidade Federal do Recôncavo da Bahia - UFRB, Centro de Ciências Agrárias, Ambientais e Biológicas - CCAAB, Campus Universitário, Rua Rui Barbosa, no 710, Bairro Centro, CEP: 44380-000, Cruz das Almas, BA, Brasil. Email: presidentesbc@gmail.com

(CRMS) Chair Man of VII CBC; Museu Paraense Emílio Goeldi, MPEG, Belém, PA, Brasil. Email: crsantos@museu-goeldi.br

(FLM) The Crustacean Society - TCS - Latin American Liason; Vice President of Asociación LatinoAmericana de Carcinología - ALCARCINUS. Departamento de Biologia, Faculdade de Filosofia, Ciências e Letras de Ribeirão Preto (FFCLRP), Universidade d São Paulo (USP), Av. Bandeirantes 3900, 14040-901, Ribeirão Preto, SP, Brasil. Email: flmantel@usp.br

During the VII Brazilian Crustacean Congress, held in Belém, Pará, from 11 to 14 November 2012, two assemblies (one extraordinary and other ordinary) of all the members of the Brazilian Crustacean Society (SBC) who were present at the event were held, in which the final reports and advances of the SBC and the journal Nauplius were presented.

\section{1) Extraordinary Assembly of the Brazilian Crustacean Society}

Vice-President Georgina Bond-Buckup opened the extraordinary meeting and explained the major changes made in the Society's statutes, stressing the need to adapt it to the Brazilian Civil Code. The changes included the creation of the Audit Committee independent from the Directorate, and setting January $2^{\text {nd }}$ as the date for the new Directorate to take office in the year following the election. The assembly voted in favor of all changes.

\section{2) Ordinary Assembly of the Brazilian Crustacean Society}

President Paula Beatriz de Araujo presented the minutes of the previous meeting (No. 15) to the members, who approved the document. The President also informed the assembly that in the year 2012 the Brazilian Crustacean Society was celebrating its thirtieth anniversary. She described the history of the
SBC since its founding, previous Directorates, the establishment of Nauplius, and the main accomplishments of each past Directorate. The assembly also formally recognized all new members admitted in 2011 and 2012. The President reported on all administrative acts taken by the Directorate during the 2011-2012 period, including: implementing a program of financial support for undergraduate and graduate students; supporting the expansion of Nauplius; supporting the organizing committee of the VII CBC; and appointing an electoral commission to conduct the election of the new Directorate for the 2013-2014 period. The first secretary, Sérgio Schwarz Rocha, reported on the main discussions and deliberations during the $5^{\text {th }}$ Meeting of the Brazilian Scientific Societies of Zoology, and Treasurer Alexandre Oliveira de Almeida presented the 20112012 financial report. Counselor Ludwig Buckup read the Council's opinion on the administrative acts and financial report of the current Directorate, in which they expressed approval of both reports. Finally, the assembly voted unanimously in favor of the Council's opinion on these matters.

The Editor of Nauplius, Fernando Mantelatto, reported on the present situation of the journal, highlighting the number of times that articles in Nauplius have been accessed through the Internet; the increase of 
the QUALIS/CAPES index from B5 to B3; the recent approval of Nauplius to be indexed in SciELO system; and the new strategies and recommendations to increase the journal quality.

The assembly voted in favor of holding the VIII CBC in Bonito, Mato Grosso do Sul, during a period to be determined by the local committee, during the year 2014. The local organizing committee is composed by Jelly Makoto Nakagaki, Liliam Hayd and others who will keep the Directorate informed about the organization of the event.

\section{The new Directorate}

During this Assembly, the new Directorate was elected, following the SBC laws. The new team that will be in front of this new management will be formed by the following researchers:

President: Sérgio Schwarz da Rocha (UFRB, BA)

Vice President: Alexandre Oliveira de Almeida (UESC, BA)

Secretary (1): Harry Boos Júnior (ICMBio, $\mathrm{SC})$

Secretary (2) Luis Ernesto Arruda Bezerra (UFRN, RN)

Treasurer (1): Cléverson Ranniéri Meira dos Santos (MPEG, PA)

Treasurer (2): Ricardo Lourenço Pinto (UNB, DF)

Councilors: Georgina Bond-Buckup (UFRS, RS), Marcelo Antonio Amaro Pinheiro (UNESP, SP), Carlos Eduardo Falavigna da Rocha (USP, SP)

The outgoing President reported his intention to: (1) develop the official website of the Brazilian Crustacean Society into a site where all SBC members can interact and communicate their research, achievements, work groups and laboratories; (2) create an exclusive area in the website where each member will be able to update his SBC registration, and access information about his membership (last payment, membership number, etc.); (3) ensure continued smooth financial transactions during transitions between Directorates; and (4) seek the inclusion of the SBC in scientific forums and governmental committees and councils.

Finally, President Araujo read a letter sent by Cristiana Serejo in which she expressed her desire to organize the IX CBC in Buzios, Rio de Janeiro in 2016. Also, some SBC members presented a motion requesting IBAMA to take into consideration that all environmental licensing for the construction of hydroelectric power plants must have reports on the crustacean fauna and the vulnerability of these populations, and that these reports must be signed by recognized experts in the field of carcinology. The assembly approved the motion.

\section{Brazilian Crustacean Congress}

Brazilian and foreign carcinologists, both members and non-members of the SBC, participated in this event, held at Hangar Centro de Convençóes e Feiras da Amazônia, in Belém, Pará, Brazil. The congress included presentations in 4 conferences, 9 round tables, 9 oral presentation sessions, 5 shortterm courses, 1 seminar and 1 workshop. There were participants from 10 countries, and 368 abstracts covering research on (1) Biodiversity and Biogeography, (2) Behavior, (3) Conservation and Sustainability, (4) Development and Reproduction, (5) Ecology, (6) Ecotoxicology, (7) Structure, Morphology and Function, (8) Evolution, Genetics and Systematics, (9) Physiology and Biochemistry, (10) Larval morphology, and (11) Fishery and Aquaculture. Dr. Cléverson Ranniéri Meira dos Santos (Museu Paraense Emílio Goeldi - MPEG) and the worker team are to be congratulated for hosting a highly successful Seventh Brazilian Crustacean Congress (VII $\mathrm{CBC}$.

The Brazilian Crustacean Society, in association with The Crustacean Society (TCS) and ALCARCINUS (Asociación Latino-Americana de Carcinología), awarded prizes for the best students presentations in the oral and poster sessions. We congratulate the two undergraduate student recipients: 
Juliana Resende Costa (UFSM) for her oral presentation "Diferenças comportamentais entre lagostins juvenis e adultos: evidências em Parastacus brasiliensis (Parastacidae)" and Gisele Rodrigues Tiseo (UNESP), for her poster presentation "Histoquimica e ultraestrutura da produção dos espermatozóides, espermatóforos e fluido seminal no siri chita Arenaeus cribrarius"; and the four graduate student recipients: Felipe Augusto Correia Monteiro (UFC) for his oral presentation " $A$ review of fossil decapods from Santana Formation, Araripe basin, northeastern Brazil, Lower Cretaceous (Albian - Aptian, 110 m.y.)", Anna Andressa Evangelista Nogueira (UFRGS) for her poster presentation "Ostracodes do Mioceno da formação Pirabas (Pará, Brasil) e da formação Cantaure (Falcón, Venezuela)", Fabrício Lopes de Carvalho (FFCLRP/USP) for his poster presentation "Status filogenético de algumas espécies de Palaemon e Palaemonetes (Decapoda, Palaemonidae) das Américas revelada com base no gene 16Sr RNA)", and Marcelo Marchet Dalosto (UFSM) for his poster presentation "Padrôes de movimento e atividade do lagostim escavador Parastacus pilimanus (Decapoda: Parastacidae), monitorados por radiotelemetria." Several renowned carcinologists attended the event. The SBC bestowed honors on Richard George Hartnoll and the Brazilian carcinologists Cristiana Serejo (MNRJ) and Célio Magalhães (INPA) in recognition of their contributions rendered to carcinology.

Additional meeting highlights included the traditional costume party, a spectacular presentation of Carimbó, Lundu, Marujada and other typical Amazon dances, and wonderful happy-hour at Estação das Docas. During the closing session of the VII CBC all participants enjoyed a delicious dinner of typical Amazonian food and had a piece of cake made especially for the celebration of the $30^{\text {th }}$ Anniversary of SBC.

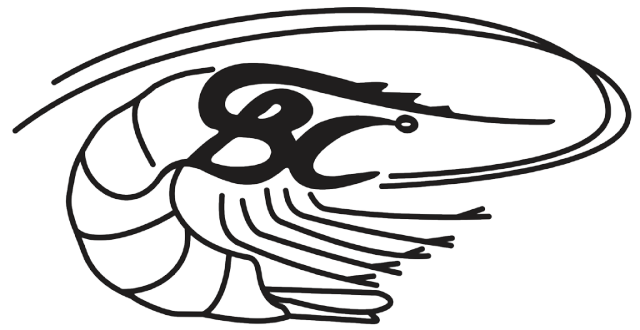

SOCIEDADE BRASILEIRA DE CARCINOLOGIA 